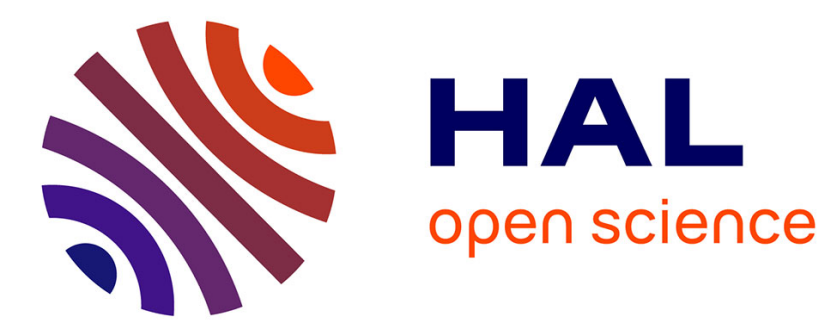

\title{
Modeling water exsolution from a growing and solidifying felsic magma body
}

\author{
Catherine Annen, Alain Burgisser
}

\section{To cite this version:}

Catherine Annen, Alain Burgisser. Modeling water exsolution from a growing and solidifying felsic magma body. Lithos, 2021, 402-403 (105799), 10.1016/j.lithos.2020.105799 . hal-02964252

\section{HAL Id: hal-02964252 \\ https://hal.science/hal-02964252}

Submitted on 12 Oct 2020

HAL is a multi-disciplinary open access archive for the deposit and dissemination of scientific research documents, whether they are published or not. The documents may come from teaching and research institutions in France or abroad, or from public or private research centers.
L'archive ouverte pluridisciplinaire HAL, est destinée au dépôt et à la diffusion de documents scientifiques de niveau recherche, publiés ou non, émanant des établissements d'enseignement et de recherche français ou étrangers, des laboratoires publics ou privés. 


\section{Modeling water exsolution from a growing and solidifying felsic magma body.}

Catherine Annen ${ }^{1,2}$, and Alain Burgisser ${ }^{1}$

${ }^{1}$ Univ. Grenoble Alpes, Univ. Savoie Mont Blanc, CNRS, IRD, IFSTTAR, ISTerre, 38000 Grenoble, France.

${ }^{2}$ School of Earth Sciences, University of Bristol, Wills Memorial Building, Queen's Road, Bristol BS8 1RJ, United Kingdom

Corresponding author: Catherine Annen. Catherine.annen@bristol.ac.uk

Abstract

We modelled water exsolution from a growing and crystalizing felsic magma body using a conductive thermal model with simplified physical mechanisms of volatile transport. Magma solidification leads to the release of the water initially dissolved in the melt. Solidification behaviour depends, in turn, on dissolved water content. The water is channelled where the magma is solidified enough to form a crystal network and rapidly ascends until it encounters solid rock or liquid-rich magma. The rate of water exsolution depends on the basal magma emplacement rate, the cooling rate, and the magma initial water content. Water-rich layers form and are eventually trapped in the solid rock as cooling and crystallization proceeds. We ran our model with a quasi-eutectic granite composition and a noneutectic monzogranite composition. The non-eutectic magma crystallises on a wider range of temperature than the eutectic magma, produces more mush, and is more prone to the formation of water-rich lenses. Exsolved water accumulates on the sides of the chamber for both tested 
compositions and also above the top of the chamber for the non-eutectic composition. The actual presence of these water-rich layers in nature and their lifetime depends on whether the water is further released by fracturing. Our results accounts for the observed decoupling of volatiles from magma and for the episodic nature of volcano deformation. It has implications for the interpretation of magma chambers tomography as water-rich lenses would be difficult to distinguish from melt-rich lenses.

Keywords: magma, volatiles, water exsolution, granite

\section{Introduction}

Magmas are mixtures of melt, crystals, and volatiles. At depth, they contain various dissolved volatile species, including $\mathrm{H}_{2} \mathrm{O}, \mathrm{CO}_{2}$, and $\mathrm{SO}_{2}$. Magma decompression or crystallization induces volatiles exsolution and formation of an independent phase of supercritical fluid.

Volatiles play an important role in volcanology. Their proportions strongly affect eruptions styles as gas-rich magmas are more explosive and hazardous than their gas-poor counterpart. The presence of exsolved volatiles also affects geophysical measurements. On the one hand, exsolved volatiles increase magma compressibility, so that magma volumes may be underestimated if based on ground surface deformation (Tait et al, 1989). On the other hand, the change in volume caused by water exsolution in closed system induces an overpressure that may lead to the rupture of the chamber walls (Blake, 1984; Fowler and Spera, 2008, 2008; Tait et al., 1989). Volatiles also affect seismic wave velocities and electrical resistivity and make magma chamber imaging difficult to interpret.

Volatiles transfer is believed to play a role in petrogenesis (Collins et al., 2020; Weinberg and Hasalová, 2015). The presence of $\mathrm{H}_{2} \mathrm{O}$ increases melt fractions. Fluxing of the crust by $\mathrm{H}_{2} \mathrm{O}$ exsolved from a magma is expected to promote crustal melting. The long-term influence of volatiles on the 
fate of magmatic systems is thus not restricted to eruptive processes. Fluxes and concentration of magmatic volatiles are also keys in the generation of ore deposits. Metals present in the magma are partitioned in the supercritical phase and transported by the volatiles towards upper levels above the magma chamber where they precipitate (Richards, 2011).

Analytical and thermodynamical models have been used to investigate the conjugate effect of crystallisation and volatiles exsolution on chamber pressure (Blake, 1984; Boichu et al., 2008; Tait et al., 1989) and magma fragmentation (Fowler and Spera, 2008) in order to evaluate the role of volatiles in triggering eruptions. Excess mass of volcanic $\mathrm{SO}_{2}$ emission suggests that volatiles separate from the magma at depth (Christopher et al., 2015; Wallace, 2001). Laboratory experiments and numerical simulations (Oppenheimer et al., 2015; Parmigiani et al., 2017, 2016) indicate that the rise of suspended bubbles in melt-rich magma is limited and that volatiles preferentially ascend in crystalrich material through fingering channels and capillary fracturing. For this paper, we built on these former studies, and modeled $\mathrm{H}_{2} \mathrm{O}$ exsolution and transport within a growing and solidifying magma body. We tested the influence of magma chamber growth rate and magma composition, including initial water content, on exsolved volatile spatial and temporal distributions.

At the pressures and temperatures inside the magma body, the exsolved volatiles are supercritical fluids; for simplicity, we still use the terms bubbles. We will also use the term water independently of its state.

\section{Numerical models}

\subsection{Magma chamber growth}

Several conceptual models of magma bodies emplacement and growth have been proposed. They include diapirism (e.g. He et al., 2009; Miller and Paterson, 1999), ballooning (e.g. Molyneux and Hutton, 2000), cauldron subsidence and stopping (e.g. Burchardt et al., 2012; Myers, 1975; 
Yoshinobu et al., 2003), and repeated additions of sills or dykes (e.g. Allibon et al., 2011; Michel et al., 2008; Miller et al., 2011). Here, we model the growth of a magma chamber by under-accretion of sills. This growth geometry is probably most common in the brittle upper crust and is supported by field observations (Grocott et al., 2009; Michel et al., 2008), geophysics (Cruden and McCaffrey, 2001), and laboratory experiments (Kavanagh et al., 2006; Menand, 2011). The presence and size of a magma chamber (defined here as a body of eruptible magma larger than a single sill) depends on the magma body emplacement rate (Annen, 2009). This emplacement rate (or growth rate or growth velocity) is the thickness of sills divided by the time interval between sill emplacements (rest interval). It is equivalent to the flux, i.e. the added volume by unit of time divided by footprint area, that is commonly used in the literature (Sliwinski et al., 2019). If emplaced in a cold crust and if the emplacement rate is low enough, the first sills completely solidify during the rest interval. With each sill intrusion, heat is transferred to the surroundings and the temperatures of the whole system increase. When temperatures are high enough, melt subsists in the sills during the rest interval. We call incubation time the moment when a magma that is liquid and eruptible (i.e. with a melt fraction $>\sim 0.5)$ starts to accumulate. Both the incubation time and the size reached by the magma chamber depend on the emplacement rate. We did not consider mechanical effects on the stability or growth of the chamber and did not allow the country rock to partially melt (Karlstrom et al., 2010). More details on the magma chamber growth model can be found in Annen et al. (2008) and Annen (2009). For the present paper, the exsolution and transfer of water was implemented in the simulation of magma chamber growth. $\mathrm{H}_{2} \mathrm{O}$ fractions, melt fractions, and temperatures are calculated both during the growth and the solidification of the magma body. We modelled the magma body growth by addition of 100-m thick sills until the total thickness of intruded material reaches $2000 \mathrm{~m}$ (Fig. 1), after which new sill injections no longer occur. The first sill is emplaced at $5.5 \mathrm{~km}$ depth and the last at $7.5 \mathrm{~km}$ depth. After the emplacement of the last sill, the simulation continues to run until no melt remains in the system. The diameter of the sills is $2000 \mathrm{~m}$. The initial temperature of the sills at the time of emplacement is their liquidus, which depends on their composition (see section 2.3). We 
tested sills emplacement rate of $1,5,10$, and $100 \mathrm{~cm} / \mathrm{yr}$. We also simulated the cooling of a $2000 \mathrm{~m}$ thick, $2000 \mathrm{~m}$ wide magma body that was instantaneously emplaced. The final geometry and volume of the intrusive body is similar for all simulations.

The simulations are run in 2D on a square grid with cylindrical coordinates. The numerical domain is $10 \mathrm{~km} \times 2.5 \mathrm{~km}$ (Fig. 1). The grid cells dimension is $25 \mathrm{~m} \times 25 \mathrm{~m}$. The initial temperatures of the numerical domain follow a linear geothermal gradient of $20^{\circ} \mathrm{C} / \mathrm{km}$. The boundary conditions are a constant temperature $\mathrm{T}=0{ }^{\circ} \mathrm{C}$ at the top of numerical domain that corresponds to the Earth surface, and no heat flow at the right and left boundaries. The horizontal dimension of the domain $(2.5 \mathrm{~km})$ was chosen so that the thermal anomaly induced by the sills does not reach the right boundary on the timescale of the simulation. The heat flux through the bottom boundary is calculated by first calculating the depth $Z_{\text {I }}$ where the temperature reaches the liquidus temperature $T_{\text {I }}$ of the emplaced magma (which varies as a function of the magma composition) according to the initial geothermal gradient. This depth is outside the numerical domain and is assumed to be the source of the magma. The bottom heat flux $Q_{B}$ is then calculated as follows:

$Q_{B}=\kappa \frac{T_{B}-T_{l}}{Z_{B}-Z_{l}}$

Where $T_{B}$ is the temperature at the bottom boundary, $Z_{B}$ is the depth of the bottom boundary $(10 \mathrm{~km})$, and $\kappa$ is the thermal conductivity.

Sills have a cylindrical geometry and pile up to build a cylindrical composite intrusion, the final shape of which is axisymmetric and isometric (Fig. 1). The volume of each new sill is accommodated by moving downwards the cells below the sill. It is an approximation of magma accommodation by chamber floor subsidence (Cruden and McCaffrey, 2001).

The finite difference formulation of the heat equation is used to calculate temperature: 
$\frac{\partial H}{\partial t}=\kappa \overrightarrow{\nabla \mathrm{T}}$

$H=\rho c T+\rho X_{m} L$

(3)

With $\rho$ the density, $c$ the specific heat capacity, $T$ the temperature, $X_{m}$ the melt mass fraction, and $L$ the latent heat of crystallisation. The list of symbols is in Table 1. Details of the discretization by finite difference of the equations can be found in Annen et al (2008). The thermal conductivity $\kappa$ depends on temperature and on the lithostatic pressure (Chapman and Furlong, 1992):

$\kappa=\kappa_{0} \frac{1+1.5 \times 10^{-6} z}{1+1 \times 10^{-4} T}$

where $\kappa_{0}$ is the thermal conductivity at surface temperature and pressure, and $z$ is depth.

The density and the specific heat capacity do not depend on temperature in our simulation in order to avoid issues with heat conservation at the system scale.

\section{$2.2 \quad$ Volatile exsolution}

In this paper, we specifically address the exsolution rate of water as the main volatile phase in magmas emplaced in the upper crust. We assume that exsolution due to decompression during ascent has occurred before magma emplacement. According to Duan (2014), in silicic melts, all $\mathrm{CO}_{2}$ might be already lost before $\mathrm{H}_{2} \mathrm{O}$ starts to exsolve. The solubility of water, $C_{w}$, is only weakly influenced by temperature and composition (Duan, 2014). It is mainly a function of pressure $P$ (Newman and Lowenstern, 2002; Schöpa et al., 2017; Sparks, 1978; Tait et al., 1989):

$C_{w}=s P^{n}$ 
with $\mathrm{s}=4.11 \times 10^{-6} \mathrm{~Pa}^{-\mathrm{n}}$, and $\mathrm{n}=0.5$ (Burnham and Jahns, 1962).

If a magma is undersaturated, dissolved $\mathrm{H}_{2} \mathrm{O}$ concentrates in the melt while the magma cools and crystallizes:

$X_{d}=\frac{X_{0}-X_{c}}{X_{m}}$

where $X_{d}$ is the weight fraction of $\mathrm{H}_{2} \mathrm{O}$ dissolved in the melt, $X_{0}$ is the initial weight fraction of water dissolved in magma, $X_{c}$ is the fraction of $\mathrm{H}_{2} \mathrm{O}$ that enters hydrous minerals, and $X_{m}$ is the weight fraction of melt. When $X_{d}$ exceeds $C_{w}$, water is exsolved.

\subsection{Melt fractions}

We based our relationship between melt fractions, dissolved water content, and temperatures on the experimental data of Whitney (1988) that were obtained at a pressure of $2 \mathrm{kbar}$. At this pressure, the solubility of water $C_{w}$ is about 6 wt\%. The relationship between melt fraction and temperature depends on the melt water content (Whitney, 1988). If the water exsolved during crystallization is transported upwards, any reheating of the material that lost its water produces a melt that is undersaturated in water. The melt fraction would then be lower than it was originally at the same temperature (Caricchi and Blundy, 2015). This effect is for the first time integrated in a numerical simulation, which allows us to estimate the error induced by neglecting the effect of water loss when modelling incrementally growing magma bodies.

Figure 2 shows the relationships between melt fraction and temperature used in the numerical simulation. To build figure 2a, we used the experimental data of Whitney (1988) for Cape Ann granite (Massachussets). The liquidus temperatures for different water content were estimated from Whitney's figure 2 (Whitney, 1988). For water-undersaturated compositions, the relationship 
between liquidus temperature $T_{l}$ and magma water content $X_{0}$ is close to linear, so that in the numerical simulation (Fig. 2):

$T_{l}=-4300 X_{0}+1200$

The melt fraction-temperature curve for a saturated composition $\left(6 \mathrm{wt} \% \mathrm{H}_{2} \mathrm{O}\right)$ is obtained by linearly interpolating between experimental data points. For magmas that are undersaturated at liquidus, saturation is reached at melt fraction $X_{m s}=\left(X_{0}-X_{c}\right) / 0.06$. The temperature $T_{s a t}$ corresponding to $X_{m s}$ is read on the saturation curve. The undersaturated curves join the saturated curve at this point, and for any lower temperatures the melt fraction is that of a saturated composition (Caricchi and Blundy, 2015). To fit Whitney's experiment data with $\mathrm{H}_{2} \mathrm{O}$ content of $1,2,3$, and 5 wt\%, we used linear curves that relies $T_{\text {sat }}$ with $800{ }^{\circ} \mathrm{C}$ and $800{ }^{\circ} \mathrm{C}$ with $T_{l}$. The melt fraction at $800{ }^{\circ} \mathrm{C}$ depends on the water content (Fig. 2a). The numerical simulation is only valid for $\mathrm{H}_{2} \mathrm{O}$ content $X_{0}$ in excess of the amount of water trapped in crystal $X_{c}$. The results are presented for $X_{c}=0.4 \mathrm{wt} \%$, which corresponds to the crystallization of about $10 \mathrm{wt} \%$ biotite. For all water contents between $0.4 \mathrm{wt} \%\left(=\mathrm{X}_{c}\right)$ and $6 \mathrm{wt} \%$ (saturation), $X_{m}\left(\mathrm{~T}=800^{\circ} \mathrm{C}\right)$ is found by interpolation.

To test the effect of the magma composition, we simulated the injection of a water-saturated and a water under-saturated Cape Ann magma. We also ran simulations with the melt fractiontemperature relationship obtained with Rhyolite-MELTS for the Mt. Capanne monzogranite composition (Barboni et al., 2015 and fig. 2b). In this last composition, we neglect the effect of $\mathrm{H}_{2} \mathrm{O}$ loss on the melt fraction-temperature curve. We will show a posteriori using the Cape Ann granite curves that this effect is insignificant. In comparison with the Cape Ann granite curve, the Mt. Capanne curve is less steep at low temperatures and the mush state, where crystals form a network and can channel water, covers a wider range of temperatures. The initial temperature of the magma at the time of emplacement is that of the liquidus and the magma is crystal-free. 


\subsection{Volatiles transport}

When saturation is exceeded, bubbles form. Their fate depends on the crystal and volatile fractions. In contrast to other models (e.g. Black and Manga, 2016), the bubbles in our model do not rise in the liquid magma, but in the mush only. For gas volume fraction $<0.5$ and crystal volume fraction $<0.4$, bubble rise velocity $v$ is controlled by Stokes law. The presence of other bubbles and of suspended crystals hinder bubble ascent and decrease their velocity. At 2 kbar, bubble diameters are typically a few tens of $\mu \mathrm{m}$ (Lyakhovsky et al., 1996). Figure 3 shows the rise velocity of $50-\mu \mathrm{m}$-diameter bubbles suspended in a melt with a viscosity of $10^{5} \mathrm{~Pa}$ s. The bubble velocity is on the order of $\mathrm{mm}$ per year. Considering the very slow rise of the bubbles, we followed Parmigiani et al (2017) in assuming that the exsolved water is immobile and remains in the magma for crystal volume fractions $<0.4$. It has been shown experimentally (Barth et al., 2019; Holtzman et al., 2012; Oppenheimer et al., 2015; Varas et al., 2015) and numerically (Parmigiani et al., 2017) that mushes are favorable environments to form permeable pathways for gas migration. For crystal volume fractions in the range $0.4-0.7$, crystals form a connected network with gas and melt confined in the interstitial space. At gas volume fraction between a critical value ${\varepsilon_{c r}}^{g}$ and 0.5 , gas viscous fingering occurs. Fingering channels allow the upwards migration of the gas through the interstitial melt within the crystal network. $\varepsilon_{\mathrm{cr}}{ }^{\mathrm{g}}$ was determined through numerical simulations by Parmigiani et al (2017):

$\varepsilon_{c r}^{g}=2.75 \varepsilon_{c}^{3}-2.79 \varepsilon_{c}^{2}+0.63 \varepsilon_{c}+0.1$

Where $\varepsilon_{c}$ is crystal volume fraction. The velocity of exsolved volatiles transported through channeling is on the order of a few $\mathrm{mm}$ to a few $\mathrm{cm}$ per seconds (Parmigiani et al., (2017). So the time needed to cross any reasonable thickness of mush is much shorter than the numerical time step of the simulation, which is $5 \mathrm{yrs}$ for a cell dimension of $25 \mathrm{~m}$. At the scale of our simulation, we consider that degassing and transport through channels are instantaneous. At each time step, the water 
exsolved in an area of magma reservoir where the crystal volume fraction is between 0.4 and 0.7 and the volatile volume fraction is between $\varepsilon_{\mathrm{cr}}^{\mathrm{g}}$ and 0.5 is transported vertically upwards until it hits a domain where these conditions are not fulfilled.

\section{Results}

\subsection{Distribution of exsolved $\mathrm{H}_{2} \mathrm{O}$}

In the simulation, the exsolved water is arrested at the interface between mush and melt-rich magma $\left(\varepsilon_{c}<0.4\right.$, bubbles are suspended) and at the interface between mush and quasi-solid material $\left(\varepsilon_{c}>0.7\right.$, bubbles are trapped by crystals). Figures 4 and 5 show how the exsolved water volume fraction and the crystal weight fraction evolve during magma chamber formation and solidification. For an igneous body growing by accretion of sills, the first sills completely solidify between two magma injections, and water can only be transported over the thickness of a single sill. Water concentrations underline the shape of these first sills (Fig. 4a-d, Fig. 5 a-d, and Fig. 6d). After an incubation period that depends on the sill emplacement rate, a magma chamber forms (Figs $4 \mathrm{e}-\mathrm{h}$ and $5 \mathrm{e}-\mathrm{h})$. Channeling and water accumulation happen at the chamber periphery where the magma cools down and turns into a mush. Magma chambers form later when the sill emplacement rate is low (Annen, 2009). In the limiting case where the emplacement rate is too low for a magma chamber to form at all over the duration of the simulation, the concentration of water is limited by the size of the sills (Fig. 6 g-i).

At injection rates high enough for a magma chamber to grow $(>\sim 1 \mathrm{~cm} / \mathrm{yr})$, the final water distribution is an integration of the syn- and post-emplacement evolutions. Post emplacement, as it cools down, the magma chamber is surrounded by a corona of mush propitious to gas channeling. As detailed below, the thickness of this mush envelope depends on magma composition (compare Fig. 4e-h and Fig. 5e-h). The concentration of water is maximum atop the mush column. The thicker is the mush, 
the more water is channeled upwards. The mush is thin at the chamber bottom because of a steep temperature gradient. Thus, the accumulation of water at the bottom of the chamber is limited, especially for the Cape Ann composition (Fig. 4). The thickest mush columns are at the outer periphery of the axisymmetric magma chamber. So exsolved water preferentially accumulates on the upper side of the chamber. The locus of maximum water concentration moves inwards as the magma chamber retracts by cooling, which leaves behind trails of high water concentration (Fig. 6a, d). As the chamber solidifies, water-rich pockets and layers get trapped in the solidified granite while the mush is water depleted.

\subsection{Magma composition}

Magma composition and volatile content affect the slopes of the melt fraction-temperature curve (fig 2). The Cape Ann granite water-saturated composition evolves along a steeper melt fractiontemperature slope than an undersaturated granite composition or the Mt. Capanne monzogranite composition. As a result, the envelope of mush around the quasi-eutectic magma chamber (Fig. 4) is narrower than that around the non-eutectic chambers (Fig. 5).

Figure 7 shows in more detail how the volume fraction of crystals, melt, and water - before any water transport - evolve with temperature. It also shows the critical gas fraction. Although granitic undersaturated compositions produce more mush than a saturated composition (Fig. 2), less volatile transport occurs through them because volatiles saturate and exsolve at lower temperature and higher crystallinity compared to saturated compositions (Fig. 7b and 8). For the Cape Ann composition with $2 \mathrm{wt} \%$ initial water, no volatile transport and accumulation occur (Fig. 7c and 8c); The water exsolves at a melt fraction $(0.27 \mathrm{wt} \%)$ that is below the critical value for channeling (Fig. 7c) and the bubbles remain trapped in the crystal-rich material. The Mt. Capanne monzogranite, water-saturated composition fosters the most transport and accumulation of volatiles (Fig. 7d). A channel-prone mush is present between solidus and about $770{ }^{\circ} \mathrm{C}$ and the gas proportion is above the critical fraction in this temperature range (Fig. $7 \mathrm{~d})$. At the end of the solidification stage $(26,000$ 
yrs on Fig. 5), a body of mush without liquid core is present for this composition. At this stage, most water concentration occurs within and atop the mush body (Fig. 5h).

\subsection{Volatiles output rates}

Figure 9 shows the cumulated mass of $\mathrm{H}_{2} \mathrm{O}$ exsolved that is assumed extractable because not trapped in the liquid magma. The water fluxes reflect the magma fluxes, i.e. they depend on the sill emplacement rate and radius (Fig. 9a). The radius is the most important parameter since it controls both the amount of magma and water available, and the cooling surface area. As expected, the exsolution rate is lowest for an undersaturated magma (Fig. 9b). The saturated, Mt. Capanne monzogranite produces exsolved volatiles at a slightly higher rate than the Cape Ann saturated granite (Fig. 9b).

\subsection{Effect of water loss on melt fractions}

We tested the effect of water loss on the evolution of melt fractions for the water-saturated Cape Ann granite. We ran simulations where the melting curve was readjusted to the new conditions in cells that previously lost water and the magma became under-saturated upon remelting, and simulations where water loss or gain has no effect on the melting curves. In the second case, only the saturation curve (blue upper curve in Fig. 2a) was used in the computation of melt fractions independently of the actual melt water content.

Water loss has no effect on melt fraction for an instantaneously emplaced body that is only cooling because there is no reheating and remelting of partially solidified magma. Since only the water that is in excess of saturation is exsolved, the melt stays saturated and remains on the saturation curve.

For an incrementally growing body, the water loss effect on melt fractions is not null but is very weak. Reheating and remelting of former sills by new ones is limited. Figure 10 shows the difference 
in melt wt\% between the two simulations. In the case shown here, i. e. for an emplacement rate of one $100 \mathrm{~m}$-thick sill every $1000 \mathrm{yrs}$, neglecting the effect of water results in a maximum melt fraction overestimation of $3 \mathrm{wt} \%$ at the outer boundary of the mush and an underestimation of less than 1 wt\% melt at the bottom of the chamber. Overall, the difference does not exceed $4 \%$ of the total melt volume in the system.

\section{Discussion}

The simulations presented in this paper provide new insights on what might happen in a growing and solidifying magma chamber. A series of processes, however, have been neglected and can be the focus of further studies.

\subsection{Volatiles channeling}

When considering volatile transport through channeling, we neglected the capillary effect, which causes a small fraction of gas to remain within the channels. The amount of gas retained depends on grain sizes and interfacial tensions between crystals and melt, which cannot easily be constrained (Edmonds and Woods, 2018) more precisely than stating that it is much smaller than $\varepsilon_{\text {cr }}{ }^{\mathrm{g}}(6-10$ vol.\%).

In our simple model, volatiles only move upwards and not sideways (e.g. Belien et al., 2010), which constrains their level of accumulation to the top of the mush columns they are issued from. The accumulation of volatiles is stopped when their proportion reach 50 vol\%, which results in volatile layering. In the real world, we expect further volatile transfer by capillary fracturing, which would result in volatile layers connection and further volatile transport toward the surface.

Since the volatiles accumulate atop the mush, the actual distribution of the volatiles depends on the geometry of the magma body. We adopted a simple geometry where the magma chamber regularly 
grows by under-accretion of sills of similar dimensions. We expect real intrusions to be more irregular and to cause different patterns of volatiles depletion and accumulation.

\subsection{Magma convection}

We neglected the possibility that the volatiles that accumulate at the base of the liquid magma chamber might be entrained in the chamber by magma convection. Magma convection is not included in our model and the cooling rates might be underestimated. Scaling of magma convection usually assumes that the magma is heated from below or cooled from above (Worster et al., 1990), whereas in our model and in nature, an intrusion of magma is cooled from both surfaces. In such case, scaling relationships linking thermal gradient, fluid viscosity, and the effects of thermal expansion to a characteristic convection velocity are generally limited to the boundary layer region (e.g. Huber et al., 2009). Estimating the rate of bubble redistribution across the convecting magma without solving for convection itself is thus a complex task. Our results suggest that neglecting volatile entrainment by magma convection is of little consequence because volatile accumulation at the base of the magma that would be subject to convective motions, although present, is limited compared to the accumulation at the sides (granite and monzogranite compositions) and atop the chamber (monzogranite composition).

\subsection{Pressure of exsolved volatile}

We do not take into account the effect of pressure change due to volatile exsolution on the phase relationship. Indeed, the increase in pressure due to water exsolution is expected to modify water solubility (Blake, 1984) until the system reaches a new pressure equilibrium (Tait et al., 1989). Taking these feedback effects into account significantly increases the complexity of the simulations and is beyond the scope of this paper. 


\subsection{Implications for natural systems}

Our simulations produce a decoupling between volatiles and magma, a process that had been inferred from the imbalance between the excess mass of $\mathrm{SO}_{2}$ released by volcanoes and the mass of erupted melt (Christopher et al., 2015; Wallace and Gerlach, 1994). However, in contrast with most conceptual models (e.g. Richards, 2011; Wallace, 2001), in our simulations bubbles are channeled by the mush instead of ascending in the liquid magma. The consequence is that accumulation of water occurs at the top of the mush and in the solidified magma rather than atop the liquid-rich magma chamber.

Pegmatites, hydrothermal veins, and drusy cavities testify to the presence of water in granites (Bartley et al., 2020). Exhumed granites have lost their water and it remains to be determined if this loss is continuous, i.e. if capillary fracturing and water transport in the solid rock are contemporaneous with exsolution and channeling through the mush. Indeed, any capillary fracturing and further water loss must be delayed for the water-rich layers generated in our numerical simulation to actually form in real intrusive bodies.

The possible presence of water-rich layers in magmatic bodies has a series of implications. Water and melt both reduce rock electrical resistivity, density, and seismic wave velocity. Thus, the presence of water in the solidified part of a magma body would affect the interpretation of tomography based on those physical properties and, if not taken into account, would lead to an overestimation of magma chamber dimensions.

High proportion of water results in the fragmentation and fluidization of the rock even at low melt fraction (Fowler and Spera, 2008). We speculate that it might play a role in the formation of schlieren structures (Ardill et al., 2020). In case of chamber failure and eruption, the entrainment of those fragmented layers from the roof could explain the common presence of older crystals and the evidence for cold storage in volcanic product (Cooper and Kent, 2014; Rubin et al., 2017). 
It has been argued that the overpressure due to volatile exsolution is high enough to fracture the wall rocks and trigger eruptions (Blake, 1984; Fowler and Spera, 2008; Tait et al., 1989; Tramontano et al., 2017). The pressure in the chamber depends on the chamber geometry and dimensions, on the magma compressibility, and on the wallrock viscoelastic properties (Jellinek and DePaolo, 2003). In our simulations, those parameters vary in time and there are gradients in phase proportion, hence in viscosity and compressibility. Computing pressures is beyond the scope of this paper. We note however that in a viscoelastic crust, the pressure is controlled by the rate of volume increase (Jellinek and DePaolo, 2003). This rate is slow since volatile exsolution is controlled by heat diffusion. This aspect was not taken into account in former studies, thus it remains to be shown if bubble exsolution can trigger eruption in a viscoelastic crust.

The flux of water released from our modeled magma is of the order $10^{7}-10^{8} \mathrm{~kg}$ per year. Comparing the flux of water from our simulations with field data is not straightforward. Data on water release from volcanic areas are scarce. The water flux is controlled both by the quantity of magma and by its cooling rate, hence by the cooling area. With radius of 1 to $2 \mathrm{~km}$, the modeled magma bodies are relatively small. With a radius of several tens of kilometers, the cooling surface area would be multiplied by 100 and the exsolution rate would also increase by orders of magnitude. The deformation recorded in the Phlegrean Fields (Italy) between 1982 and 1984 has been linked to the crystallization of $0.83 \mathrm{~km}^{3}$ of magma and the release of $\sim 6.2 \times 10^{10} \mathrm{~kg}$ of $\mathrm{H}_{2} \mathrm{O}$ (Bodnar et al., 2007). According to Bodnar et al (2007), this water may have been trapped beneath an impermeable layer before being suddenly released when this layer was breached. More generally, ground deformation is often episodic and the volcanoes are said to be breathing. The source of the deformation is attributed to magma (Battaglia et al., 1999; Parks et al., 2012) or to volatiles transport (Bodnar et al., 2007; Vargas et al., 2017). If volatiles are involved, the episodic aspect of deformation suggests that water is able to accumulate before being released by fracturing events (Christopher et al., 2015).

Conceptual models for the generation of porphyry copper deposits involve metal transport through volatiles-rich dykes originating from the top of a magma chamber (see Fig. 7 in Richards, 2011). If, as 
our simulations suggest, water accumulates preferentially at the chamber sides and if it plays a role in the initiation of dykes, we expect volatiles-rich dykes to be initiated from the sides of the chamber. Interestingly, on a reconstruction of the Yerington batholith based on field exposure, the source of the dykes associated with mineralization originates mostly from the side of the granite body (see Fig.1 in Schöpa et al., 2017). Whether this match of locations is fortuitous or not warrants further investigation.

Since water-undersaturated Cape Ann granite produces less melt than when it is saturated, Caricchi and Blundy (2015) argue that the effect of water loss needs to be taken into account in modeling of incremental magma emplacement. Our results shed a different light on this issue as they show that, in case of incremental emplacement with injection of a magma of Cape Ann granite composition, the effect of water loss on melt production is not significant. This is because re-melting of previously emplaced sills is limited. Indeed, if the preceding sill is already cold, reheating by the new sill is not enough for the cold sill to reach solidus. If the preceding sill is still hot, i.e. above about $700^{\circ} \mathrm{C}$, it has not lost its water by the time the new sill is emplaced and its melting curve remains identical. The situation might be different if the new magma is of different composition and much hotter than the resident magma.

\section{Conclusions}

We simulated volatile exsolution and transport within a growing and solidifying magma body. Transport of water through the mush results in an efficient decoupling of water and magma. Our simulations suggest that the geometry and size of the mush that surrounds a magma chamber controls volatiles transfer and accumulation. If the water does not escape immediately through solid rock fracturing, water-rich pockets get trapped in the roof and walls of the intrusive body upon solidification. Magma compositions that are water-saturated but non-eutectic are most susceptible to transfer, concentrate, and eventually expel water compared to eutectic compositions. In contrast, 
if the magma is strongly under-saturated, water exsolves when the crystal content is already high and cannot move upwards and accumulate.

The accumulation and eventual sudden release of water could explain the episodic deformation of volcanoes. The possible presence of water-rich layers in the solidified roof and wall of a magma chamber could lead to an overestimation of the magma reservoir size if not taken into account when interpreting magma chamber tomography.

If bubbles play a role in the rupture of a magma reservoir and the initiation of dykes, our result that water accumulates atop the mush rather than atop the liquid magma might explain why many erupted magmas are crystal rich.

\section{Acknowledgements}

CA was supported by the European Union's Horizon 2020 research and innovation programme under the Marie Sklodowska-Curie grant agreement No. 794594 and by a grant from the Institut Rhônalpin des Systèmes Complexes. We thank three anonymous reviewers for helping us to improve and clarify the manuscript.

\section{References}

Allibon, J., Bussy, F., Lewin, E., Darbellay, B., 2011. The tectonically controlled emplacement of a vertically sheeted gabbro-pyroxenite intrusion: Feeder-zone of an ocean-island volcano (Fuerteventura, Canary Islands). Tectonophysics 500, 78-97.

Annen, C., 2009. From plutons to magma chambers: Thermal constraints on the accumulation of eruptible silicic magma in the upper crust. Earth and Planetary Science Letters 284, 409-416. https://doi.org/10.1016/j.epsl.2009.05.006 
Annen, C., Pichavant, M., Bachmann, O., Burgisser, A., 2008. Conditions for the growth of a long-lived shallow crustal magma chamber below Mount Pelee volcano (Martinique, Lesser Antilles Arc). journal of Geophysical Research 113. https://doi.org/doi:10.1029/2007JB005049

Ardill, K.E., Paterson, S.R., Stanback, J., Alasino, P.H., King, J.J., Crosbie, S., 2020. Schlieren-bound magmatic structures record crystal flow-sorting in dynamic upper-crustal magma-mush chambers. Front. Earth Sci. 8. https://doi.org/10.3389/feart.2020.00190

Barboni, M., Annen, C., Schoene, B., 2015. Evaluating the construction and evolution of upper crustal magma reservoirs with coupled $\mathrm{U} / \mathrm{Pb}$ zircon geochronology and thermal modeling: $\mathrm{A}$ case study from the Mt. Capanne pluton (Elba, Italy). Earth and Planetary Science Letters 432, 436-448. https://doi.org/10.1016/j.epsl.2015.09.043

Barth, A., Edmonds, M., Woods, A., 2019. Valve-like dynamics of gas flow through a packed crystal mush and cyclic strombolian explosions. Scientific Reports 9, 821. https://doi.org/10.1038/s41598-018-37013-8

Bartley, J.M., Glazner, A.F., Stearns, M.A., Coleman, D.S., 2020. The Granite Aqueduct and Autometamorphism of Plutons. Geosciences 10, 136. https://doi.org/10.3390/geosciences10040136

Battaglia, M., Roberts, C., Segall, P., 1999. Magma Intrusion Beneath Long Valley Caldera Confirmed by Temporal Changes in Gravity. Science 285, 2119-2122. https://doi.org/10.1126/science.285.5436.2119

Belien, I.B., Cashman, K.V., Rempel, A.W., 2010. Gas accumulation in particle-rich suspensions and implications for bubble populations in crystal-rich magma. Earth and Planetary Science Letters 297, 133-140. https://doi.org/10.1016/j.epsl.2010.06.014

Black, B.A., Manga, M., 2016. The eruptibility of magmas at Tharsis and Syrtis Major on Mars. Journal of Geophysical Research: Planets 121, 944-964. https://doi.org/10.1002/2016JE004998 
Blake, S., 1984. Volatile oversaturation during the evolution of silicic magma chambers as an eruption trigger. Journal of Geophysical Research: Solid Earth 89, 8237-8244. https://doi.org/10.1029/JB089iB10p08237

Bodnar, R.J., Cannatelli, C., De Vivo, B., Lima, A., Belkin, H.E., Milia, A., 2007. Quantitative model for magma degassing and ground deformation (bradyseism) at Campi Flegrei, Italy: Implications for future eruptions. Geol 35, 791. https://doi.org/10.1130/G23653A.1

Boichu, M., Villemant, B., Boudon, G., 2008. A model for episodic degassing of an andesitic magma intrusion. Journal of Geophysical Research: Solid Earth 113. https://doi.org/10.1029/2007JB005130

Burchardt, S., Tanner, D., Krumbholz, M., 2012. The Slaufrudalur pluton, southeast Iceland-An example of shallow magma emplacement by coupled cauldron subsidence and magmatic stoping. GSA Bulletin 124, 213-227. https://doi.org/10.1130/B30430.1

Burnham, C.W., Jahns, R.H., 1962. A method for determining the solubility of water in silicate melts. Am J Sci 260, 721-745. https://doi.org/10.2475/ajs.260.10.721

Caricchi, L., Blundy, J., 2015. Experimental petrology of monotonous intermediate magmas. Geological Society, London, Special Publications 422, 105-130. https://doi.org/10.1144/sp422.9

Chapman, D.S., Furlong, K.P., 1992. Thermal state of the continental lower crust. in Continental lower crust ed. By D.M. Fountain, R.Arculus, R.W. Kay, Developments in Geotectonics, Elsevier 23, 179-199.

Christopher, T.E., Blundy, J., Cashman, K., Cole, P., Edmonds, M., Smith, P.J., Sparks, R.S.J., Stinton, A., 2015. Crustal-scale degassing due to magma system destabilization and magma-gas decoupling at Soufrière Hills Volcano, Montserrat. Geochemistry, Geophysics, Geosystems 16, 2797-2811. https://doi.org/10.1002/2015GC005791

Collins, W.J., Murphy, J.B., Johnson, T.E., Huang, H.-Q., 2020. Critical role of water in the formation of continental crust. Nat. Geosci. 13, 331-338. https://doi.org/10.1038/s41561-020-0573-6 
Cooper, K.M., Kent, A.J.R., 2014. Rapid remobilization of magmatic crystals kept in cold storage (vol 506, pg 480, 2014). Nature 508, 554-554. https://doi.org/10.1038/nature13280

Cruden, A.R., McCaffrey, K.J.W., 2001. Growth of plutons by floor subsidence: Implications for rates of emplacement, intrusion spacing and melt-extraction mechanisms. Phys. Chem. Earth Pt. ASolid Earth Geod. 26, 303-315.

Duan, X., 2014. A general model for predicting the solubility behavior of $\mathrm{H} 2 \mathrm{O}-\mathrm{CO} 2$ fluids in silicate melts over a wide range of pressure, temperature and compositions. Geochimica et Cosmochimica Acta 125, 582-609. https://doi.org/10.1016/j.gca.2013.10.018

Edmonds, M., Woods, A.W., 2018. Exsolved volatiles in magma reservoirs. Journal of Volcanology and Geothermal Research 368, 13-30. https://doi.org/10.1016/j.jvolgeores.2018.10.018

Fowler, S.J., Spera, F.J., 2008. Phase equilibria trigger for explosive volcanic eruptions. Geophysical Research Letters 35. https://doi.org/10.1029/2008GL033665

Grocott, J., Arevalo, C., Welkner, D., Cruden, A., 2009. Fault-assisted vertical pluton growth: Coastal Cordillera, north Chilean Andes. Journal of the Geological Society 166, 295-301.

He, B., Xu, Y.-G., Paterson, S., 2009. Magmatic diapirism of the Fangshan pluton, southwest of Beijing, China. Journal of Structural Geology 31, 615-626. https://doi.org/10.1016/j.jsg.2009.04.007

Holtzman, R., Szulczewski, M.L., Juanes, R., 2012. Capillary Fracturing in Granular Media. Physical Review Letters 108. https://doi.org/10.1103/PhysRevLett.108.264504

Huber, C., Bachmann, O., Manga, M., 2009. Homogenization processes in silicic magma chambers by stirring and mushification (latent heat buffering). Earth and Planetary Science Letters 283, 38-47. https://doi.org/10.1016/j.epsl.2009.03.029

Jellinek, A.M., DePaolo, D.J., 2003. A model for the origin of large silicic magma chambers: precursors of caldera-forming eruptions. Bulletin of Volcanology 65, 363-381. 
Karlstrom, L., Dufek, J., Manga, M., 2010. Magma chamber stability in arc and continental crust. Journal of Volcanology and Geothermal Research 190, 249-270. https://doi.org/10.1016/j.jvolgeores.2009.10.003

Kavanagh, J.L., Menand, T., Sparks, R.S.J., 2006. An experimental investigation of sill formation and propagation in layered elastic media. Earth and Planetary Science Letters 245, 799-813. Lyakhovsky, V., Hurwitz, S., Navon, O., 1996. Bubble growth in rhyolitic melts: experimental and numerical investigation. Bulletin of Volcanology 58, 19-32. https://doi.org/10.1007/s004450050122

Menand, T., 2011. Physical controls and depth of emplacement of igneous bodies: A review. Tectonophysics 500, 11-19.

Michel, J., Baumgartner, L.P., Putlitz, B., Schaltegger, U., Ovtcharova, M., 2008. Incremental growth of the Patagonian Torres del Paine laccolith over 90 k.y. Geology 36, 459-462. https://doi.org/10:1130/G25546A.1

Miller, C.F., Furbish, D.J., Walker, B.A., Clairborne, L.L., Koteas, G.C., Bleick, H.A., Miller, J.S., 2011. Growth of plutons by incremental emplacement of sheets in crystal-rich host: Evidence from Miocene intrusions of the Colorado River Region, Nevada, USA. Tectonophysics 500, 65-77.

Miller, R.B., Paterson, S.R., 1999. In defense of magmatic diapirs. Journal of Structural Geology 21, $1161-1173$.

Molyneux, S.J., Hutton, D.H.W., 2000. Evidence for significant granite space creation by the ballooning mechanism: The example of the Ardara pluton, Ireland. GSA Bulletin 112, 15431558. https://doi.org/10.1130/0016-7606(2000)112<1543:EFSGSC>2.0.CO;2

Myers, J.S., 1975. Cauldron Subsidence and Fluidization: Mechanisms of Intrusion of the Coastal Batholith of Peru into Its Own Volcanic Ejecta. GSA Bulletin 86, 1209-1220. https://doi.org/10.1130/0016-7606(1975)86<1209:CSAFMO>2.0.CO;2

Newman, S., Lowenstern, J.B., 2002. VOLATILECALC: a silicate melt-H2O-CO2 solution model written in Visual Basic for excel. Computers \& Geosciences 28, 597-604. 
Oppenheimer, J., Rust, A.C., Cashman, K.V., Sandnes, B., 2015. Gas migration regimes and outgassing in particle-rich suspensions. Front. Phys. 3. https://doi.org/10.3389/fphy.2015.00060

Parks, M.M., Biggs, J., England, P., Mather, T.A., Nomikou, P., Palamartchouk, K., Papanikolaou, X., Paradissis, D., Parsons, B., Pyle, D.M., Raptakis, C., Zacharis, V., 2012. Evolution of Santorini Volcano dominated by episodic and rapid fluxes of melt from depth. Nature Geosci 5, 749754. http://www.nature.com/ngeo/journal/v5/n10/abs/ngeo1562.html\#supplementaryinformation

Parmigiani, A., Degruyter, W., Leclaire, S., Huber, C., Bachmann, O., 2017. The mechanics of shallow magma reservoir outgassing. Geochem. Geophys. Geosyst. 18, 2887-2905. https://doi.org/10.1002/2017GC006912

Parmigiani, A., Faroughi, S., Huber, C., Bachmann, O., Su, Y., 2016. Bubble accumulation and its role in the evolution of magma reservoirs in the upper crust. Nature 532, 492-495. https://doi.org/10.1038/nature17401 http://www.nature.com/nature/journal/v532/n7600/abs/nature17401.html\#supplementary -information

Richards, J.P., 2011. Magmatic to hydrothermal metal fluxes in convergent and collided margins. Ore Geology Reviews 40, 1-26. http://dx.doi.org/10.1016/j.oregeorev.2011.05.006

Rubin, A.E., Cooper, K.M., Till, C.B., Kent, A.J.R., Costa, F., Bose, M., Gravley, D., Deering, C., Cole, J., 2017. Rapid cooling and cold storage in a silicic magma reservoir recorded in individual crystals. Science 356, 1154-1156. https://doi.org/10.1126/science.aam8720

Schöpa, A., Annen, C., Dilles, J.H., Sparks, R.S.J., Blundy, J.D., 2017. Magma Emplacement Rates and Porphyry Copper Deposits: Thermal Modelling of the Yerington Batholith, Nevada, USA. Economic Geology 112, 1653-1672.

Sliwinski, J., Farsky, D., Lipman, P.W., Guillong, M., Bachmann, O., 2019. Rapid Magma Generation or Shared Magmatic Reservoir? Petrology and Geochronology of the Rat Creek and Nelson 
Mountain Tuffs, CO, USA. Frontiers in Earth Science 7, 271. https://doi.org/10.3929/ethz-b000380665

Sparks, R.S.J., 1978. The dynamics of bubble formation and growth in magmas: A review and analysis. Journal of Volcanology and Geothermal Research 3, 1-37. https://doi.org/10.1016/03770273(78)90002-1

Tait, S., Jaupart, C., Vergniolle, S., 1989. Pressure gas content and eruption periodicity of a shallow, crystallising magma chamber. Earth and Planetary Science Letters 92, 107-123.

Tramontano, S., Gualda, G.A.R., Ghiorso, M.S., 2017. Internal triggering of volcanic eruptions: tracking overpressure regimes for giant magma bodies. Earth and Planetary Science Letters 472, 142-151. https://doi.org/10.1016/j.epsl.2017.05.014

Varas, G., Ramos, G., Géminard, J.-C., Vidal, V., 2015. Flow and fracture in water-saturated, unconstrained granular beds. Front. Phys. 3. https://doi.org/10.3389/fphy.2015.00044

Vargas, C.A., Koulakov, I., Jaupart, C., Gladkov, V., Gomez, E., Khrepy, S.E., Al-Arifi, N., 2017. Breathing of the Nevado del Ruiz volcano reservoir, Colombia, inferred from repeated seismic tomography. Sci Rep 7, 1-6. https://doi.org/10.1038/srep46094

Wallace, P.J., 2001. Volcanic SO2 emissions and the abundance and distribution of exsolved gas in magma bodies. Journal of Volcanology and Geothermal Research 108, 85-106. https://doi.org/10.1016/S0377-0273(00)00279-1

Wallace, P.J., Gerlach, T.M., 1994. Magmatic Vapor Source for Sulfur Dioxide Released During Volcanic Eruptions: Evidence from Mount Pinatubo. Science 265, 497. https://doi.org/10.1126/science.265.5171.497

Weinberg, R.F., Hasalová, P., 2015. Water-fluxed melting of the continental crust: A review. Lithos 212-215, 158-188. https://doi.org/10.1016/j.lithos.2014.08.021

Whitney, J.A., 1988. The Origin of Granite - the Role and Source of Water in the Evolution of Granitic Magmas. Geological Society of America Bulletin 100, 1886-1897. 
Worster, M.G., Huppert, H.E., Sparks, R.S.J., 1990. Convection and Crystallization in Magma Cooled from Above. Earth and Planetary Science Letters 101, 78-89.

Yoshinobu, A.S., Fowler, J., Paterson, S.R., Llambias, E., Tickyj, H., Sato, A.M., 2003. A view from the roof: magmatic stoping in the shallow crust, Chita pluton, Argentina. Journal of Structural Geology 25, 1037-1048.

Figure captions

Figure 1: Model setup. The numerical half domain is a grid $10 \mathrm{~km} \times 2.5 \mathrm{~km}$ with cells $25 \mathrm{~m} \times 25 \mathrm{~m}$. The system is axisymmetric. The radius of the magma body is $1 \mathrm{~km}$ and its final thickness is $2 \mathrm{~km}$.

Figure 2: Relationships between melt fractions (wt\%) and temperatures. (a) Cape Ann granite composition (Whitney, 1988). The relationship varies with water content. The symbols show the positions of experiment data points from Whitney(1988). (b) Mt. Capanne monzogranite composition saturated with water (modified from Barboni et al., 2015).

Figure 3: Ascent velocity of gas bubbles as a function of crystal volume fraction. The velocity is calculated with equations B4 to B7 in Parmigiani et al (2017). The bubbles radius is $50 \mu \mathrm{m}$.

Figure 4: Snapshots of magma chamber formation and solidification. Upper row: Exsolved water volume fraction; Lower row: crystal wt fraction relative to melt. 100-m sills are emplaced every 1000 yrs during 20,000 yrs. After $20,000 \mathrm{yrs}$, temperatures relax and the magma chamber contracts. The composition is Cape Ann granite (Whitney, 1988) initially saturated in $\mathrm{H}_{2} \mathrm{O}$.

Figure 5: As figure 4 for water-saturated Mt. Capanne monzogranite (Barboni et al., 2015). 
Figure 6: Exsolved water in wt\% at the end of simulations. The composition is Cape Ann granite (Whitney, 1988) and was initially saturated with 6 wt\% water. Half-domain cross sections are shown on the left; vertical profiles of water contents close to the igneous body central axis are shown in the middle; vertical profiles of water contents closer to the igneous body outer edge are shown on the right. (a) (b) (c): The magma chamber was instantaneously emplaced. (d) (e) (f): 100-m sills were emplaced every 1000 years. (g) (h) (i): 100-m sills were emplaced every 10,000 yrs.

Figure 7: Proportions of crystals, melts, and exsolved volatiles before transport as a function of temperature. (a) a saturated Cape Ann granite, (b) Cape Ann granite with 4 wt\% $\mathrm{H}_{2} \mathrm{O}$, (c) Cape Ann granite with 2 wt\% $\mathrm{H}_{2} \mathrm{O}$, (d) a saturated Mt. Capanne monzogranite. The grey area shows the temperature range over which transport through channels happens, i.e. where the volatile curve is above the critical volatile fraction and the crystal fraction is between 0.4 and 0.7 . No transport occurs for the granite with $2 \mathrm{wt} \% \mathrm{H}_{2} \mathrm{O}$ (c), because the proportion of exsolved volatiles never exceeds the critical value.

Figure 8: Snapshots of exsolved water volume fraction. In these simulations, 100-m sills were emplaced every 1,000 yrs during 20,000 yrs. All snapshots are at time 22,000 yrs, i.e 2000 yrs after the last sill emplacement. Results are shown for a Cape Ann granite composition that initially contains (a) 6 wt $\% \mathrm{H}_{2} \mathrm{O}$, (b) 4 wt \% $\mathrm{H}_{2} \mathrm{O}$, (c) 2 wt $\% \mathrm{H}_{2} \mathrm{O}$, and (d) for the Mt. Capanne monzogranite that initially contains $6 \mathrm{wt} \% \mathrm{H}_{2} \mathrm{O}$. The red lines on the snapshots show the 0.4 and 0.7 crystal volume fraction isolines and delimit the areas where water in transported through channels. These areas are very thin in (a) and (b). In (c), there is no magma with crystal fraction below 40 vol\%. (e) and (f) are enlargement of (a) and (d), respectively. 
Figure 9: Cumulated mass of exsolved water available as a function of time. We assume that the volatiles in suspension as bubbles in the liquid magma are unavailable and are excluded from the calculation. (a) Exsolved water for different emplacement rates and sills radii corresponding to magma fluxes of $0.3 \mathrm{~km}^{3} / \mathrm{yr}$ for $1 \mathrm{~km}$ radius and $0.1 \mathrm{~m} / \mathrm{yr}$ emplacement, $0.03 \mathrm{~km} / \mathrm{yr}$ for $1 \mathrm{~km}$ radius and $0.01 \mathrm{~m} / \mathrm{yr}$ emplacement, and $1.26 \mathrm{~km}^{3} / \mathrm{yr}$ for $2 \mathrm{~km}$ radius and $0.1 \mathrm{~m} / \mathrm{yr}$ emplacement. The composition is Cape Ann water-saturated granite. (b) Exsolved water for different compositions of magma emplaced at the same rate of $0.01 \mathrm{~m} / \mathrm{yr}$ and same sill radius of $1 \mathrm{~km}$. The total and final mass of water exsolved is shown by the horizontal dashed lines.

Figure 10: Effect of water loss on melt fractions. The colors show the difference in melt mass fractions in wt\% between a model that takes into account water loss and a model that neglects the effect of water loss on the melting curves. The composition is water-saturated Cape Ann granite. $100-\mathrm{m}$ sills were emplaced every 1000 yrs during 20,000 yrs. The snapshot is taken at time 22,000 yrs, which is 2000 yrs after the last sill emplacement. 
Table 1: list of symbols and units. Their value or the equation used to calculate them is given when relevant.

\begin{tabular}{|c|c|c|c|}
\hline$c$ & specific heat capacity & 1100 & $\mathrm{~J} \mathrm{~K}^{-1} \mathrm{~kg}^{-1}$ \\
\hline$t$ & time & & s \\
\hline$z$ & depth & & $\mathrm{m}$ \\
\hline$C_{w}$ & $\mathrm{H}_{2} \mathrm{O}$ solubility & 6 & wt\% \\
\hline$H$ & Heat content & eq. 3 & $\mathrm{~J} \mathrm{~m}^{-3}$ \\
\hline$L$ & latent heat & 350,000 & $\mathrm{~J} \mathrm{~kg}^{-1}$ \\
\hline$P$ & pressure & & kbar \\
\hline$Q_{B}$ & bottom boundary heat flux & eq. 1 & $W m^{-2}$ \\
\hline$T$ & temperature & & ${ }^{\circ} \mathrm{C}$ \\
\hline$T_{B}$ & numerical domain bottom temperature & & ${ }^{\circ} \mathrm{C}$ \\
\hline$T_{1}$ & liquidus temperature & eq. 7 & ${ }^{\circ} \mathrm{C}$ \\
\hline$T_{\text {sat }}$ & saturation temperature & & ${ }^{\circ} \mathrm{C}$ \\
\hline$x_{0}$ & initially dissolved $\mathrm{H}_{2} \mathrm{O}$ mass fraction & & \\
\hline$X_{c}$ & $\mathrm{H}_{2} \mathrm{O}$ mass fraction in minerals & 0.4 & wt\% \\
\hline$x_{d}$ & dissolved $\mathrm{H}_{2} \mathrm{O}$ mass fraction & & \\
\hline$X_{m}$ & melt mass fraction & & \\
\hline$X_{m s}$ & melt mass fraction at saturation & & \\
\hline$Z_{B}$ & numerical domain bottom boundary dep & pth & $\mathrm{km}$ \\
\hline$Z_{1}$ & depth of liquidus & & $\mathrm{km}$ \\
\hline$\varepsilon_{g}$ & gas volume fraction & & \\
\hline$\varepsilon_{c r}^{g}$ & critical gas volume fraction & & \\
\hline$\varepsilon_{c}$ & crystal volume fraction & & \\
\hline$\kappa$ & thermal conductivity & eq. 4 & $W m^{-1} K^{-1}$ \\
\hline$\kappa_{0}$ & thermal conductivity at Earth's surface & 2.25 & $W m^{-1} K^{-1}$ \\
\hline$\rho$ & density & 2600 & $\mathrm{~kg} \mathrm{~m}^{-3}$ \\
\hline
\end{tabular}




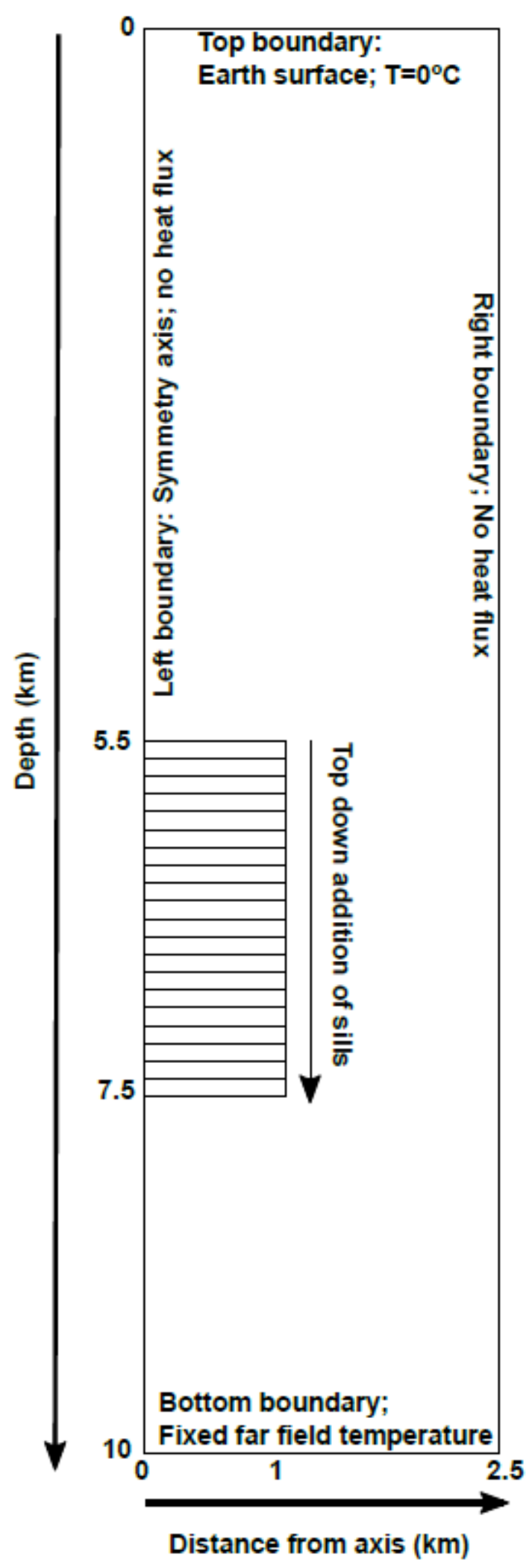

Figure 1: Model setup. The numerical half domain is a grid $10 \mathrm{~km} \times 2.5 \mathrm{~km}$ with cells $25 \mathrm{~m} \times 25 \mathrm{~m}$. The system is axisymmetric. The radius of the magma body is $1 \mathrm{~km}$ and its final thickness is $2 \mathrm{~km}$. 

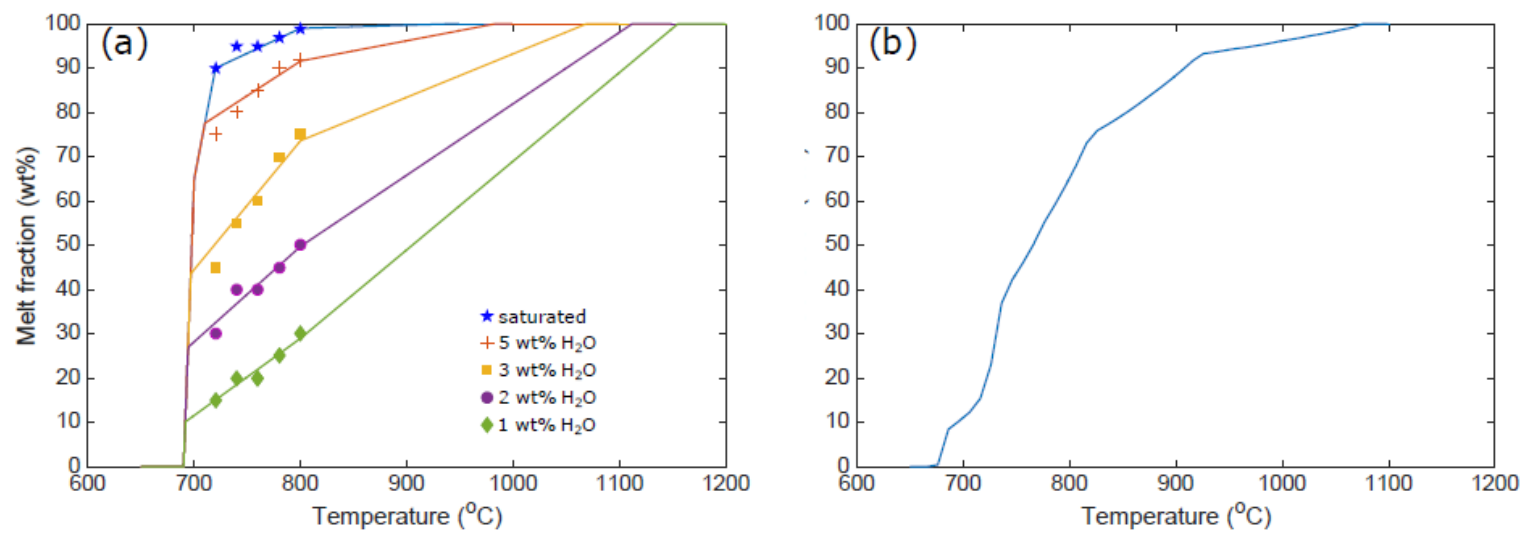

Figure 2: Relationships between melt fractions (wt\%) and temperatures. (a) Cape Ann granite composition (Whitney, 1988). The relationship varies with water content. The symbols show the positions of experiment data points from Whitney (1988). (b) Mt. Capanne monzogranite composition saturated with water (modified from Barboni et al., 2015). 


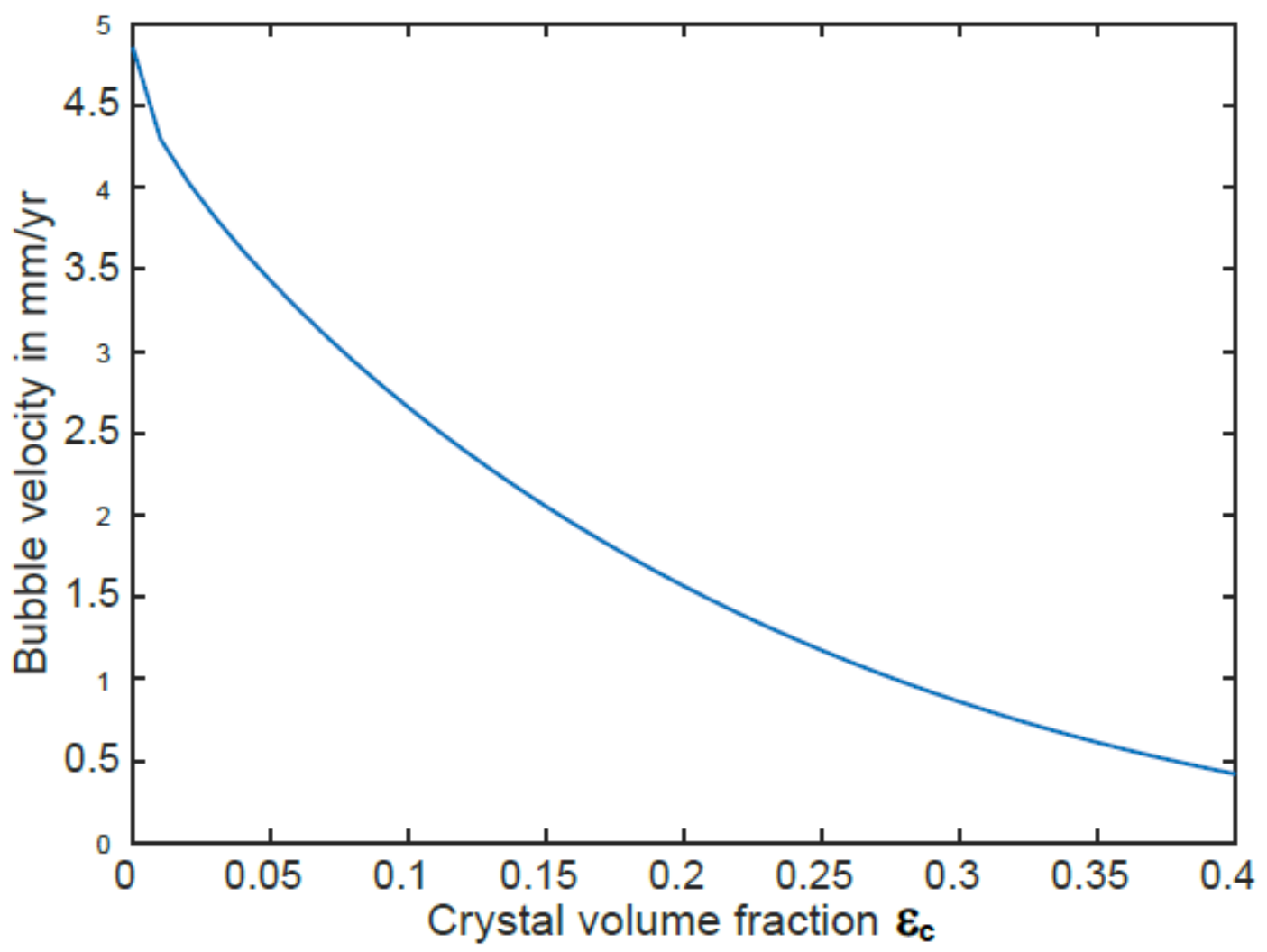

Figure 3: Ascent velocity of gas bubbles as a function of crystal volume fraction. The velocity is calculated with equations B4 to B7 in Parmigiani et al (2017). The bubbles radius is 50 lam. 


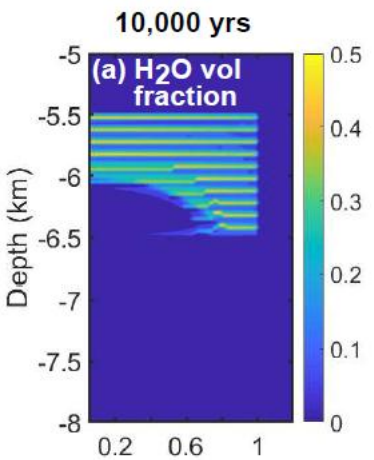

Distance from axis $(\mathrm{km})$

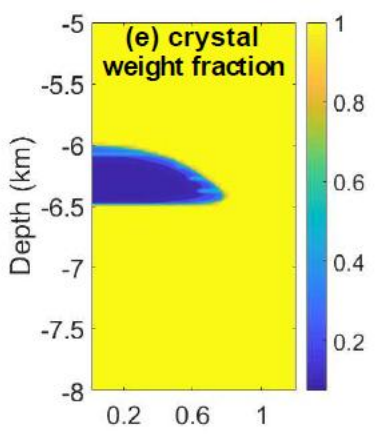

Distance from axis $(\mathrm{km})$

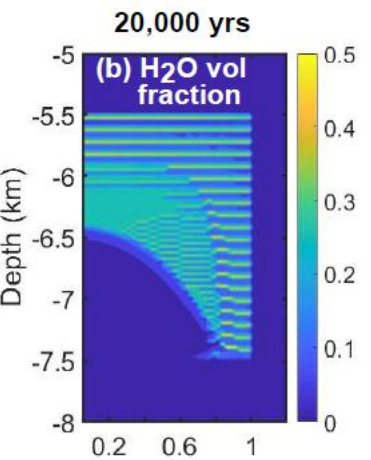

Distance from axis $(\mathrm{km})$

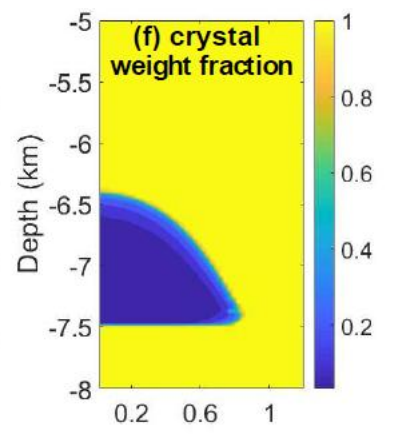

Distance from axis $(\mathrm{km})$

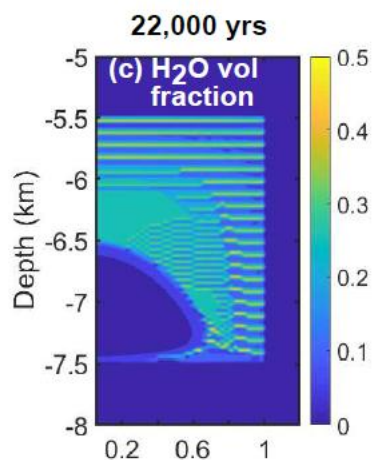

Distance from axis $(\mathrm{km})$

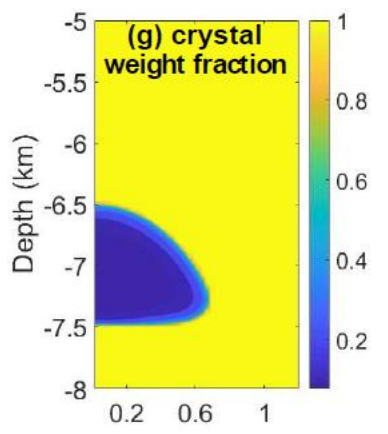

Distance from axis (km)

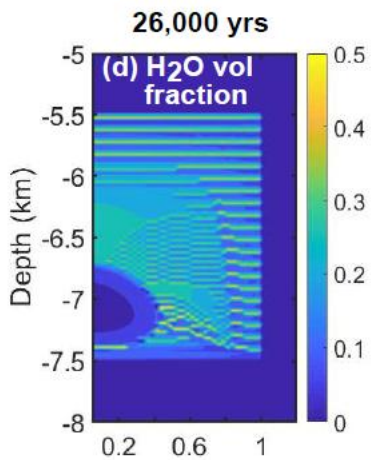

Distance from axis $(\mathrm{km})$

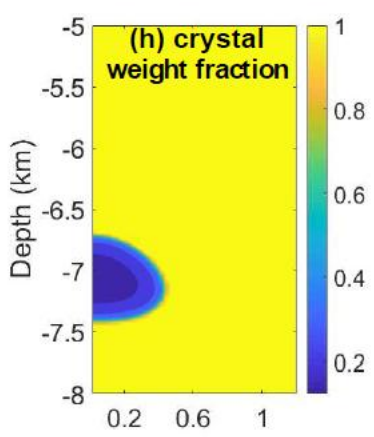

Distance from axis $(\mathrm{km})$

Figure 4: Snapshots of magma chamber formation and solidification. Upper row: Exsolved water volume fraction; Lower row: crystal wt fraction relative to melt. 100-m sills are emplaced every 1000 yrs during 20,000 yrs. After 20,000 yrs, temperatures relax and the magma chamber contracts. The composition is Cape Ann granite (Whitney, 1988) initially saturated in H2O. 

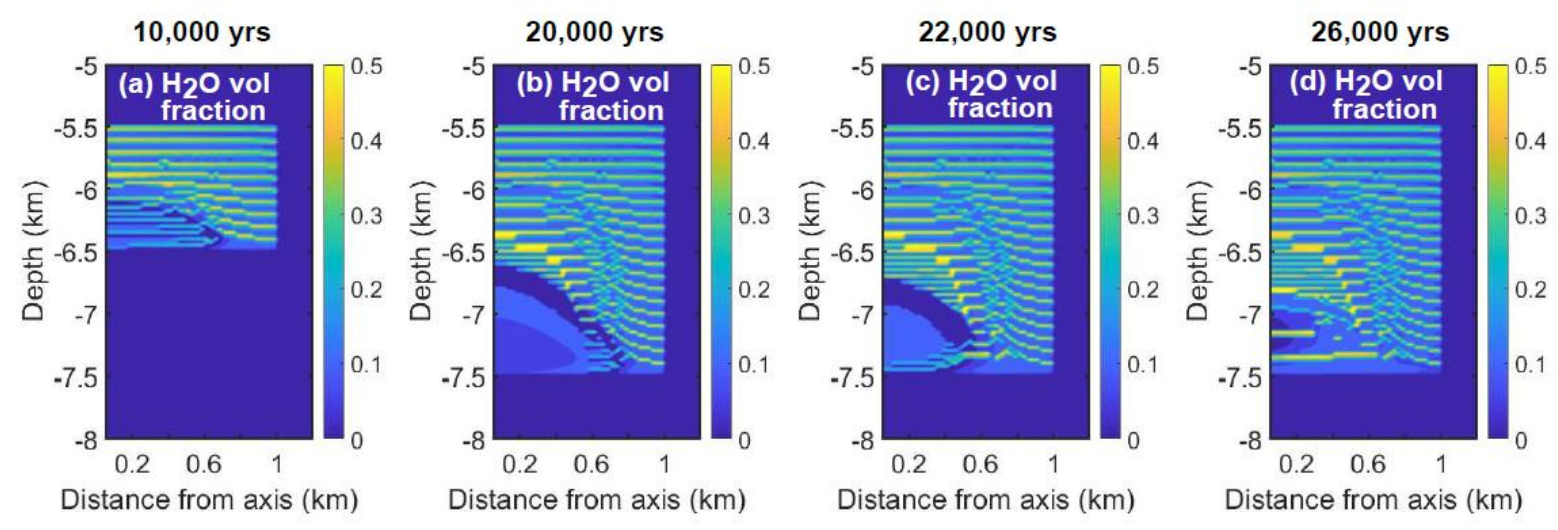

Distance from axis $(\mathrm{km})$
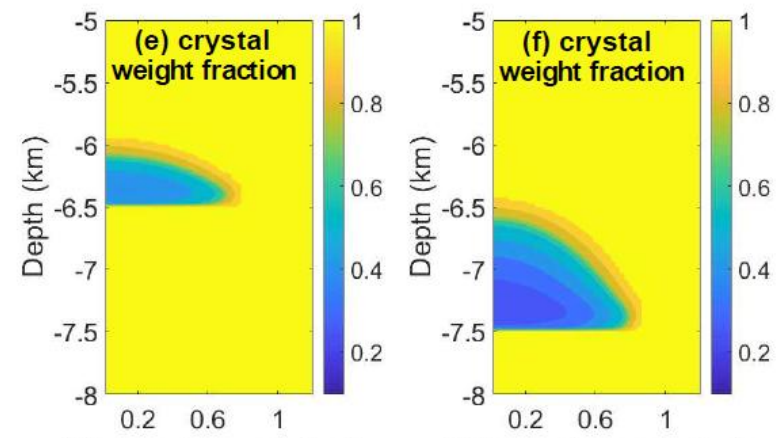

Distance from axis $(\mathrm{km})$

Distance from axis $(\mathrm{km})$

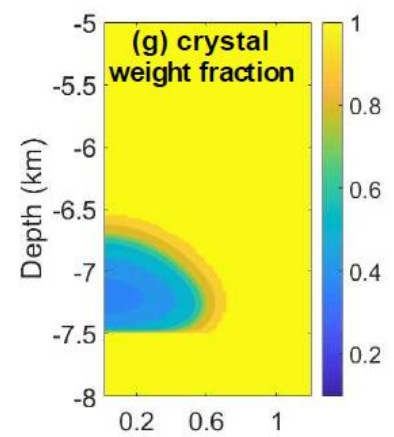

Distance from axis $(\mathrm{km})$

Figure 5: As figure 4 for water-saturated Mt. Capanne monzogranite (Barboni et al., 2015). 

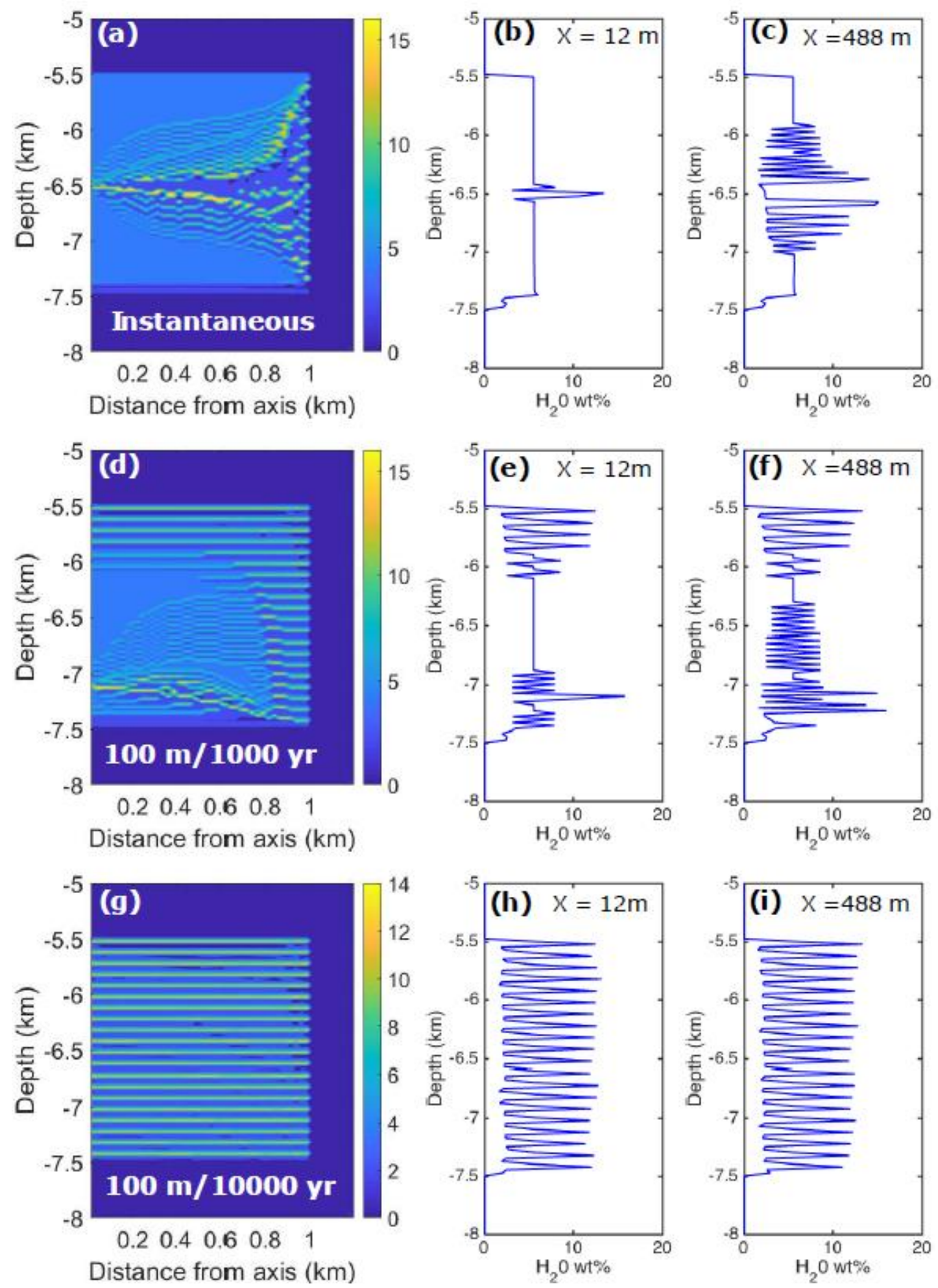

Figure 6: Exsolved water in wt\% at the end of simulations. The composition is Cape Ann granite (Whitney, 1988) and was initially saturated with 6 wt\% water. Half-domain cross sections are shown on the left; vertical profiles of water contents close to the igneous body central axis are shown in the middle; vertical profiles of water contents closer to the igneous body outer edge are shown on the right. (a) (b) (c): The magma chamber was instantaneously emplaced. (d) (e) (f): 100-m sills were emplaced every 1000 years. (g) (h) (i): 100-m sills were emplaced every 10,000 yrs. 

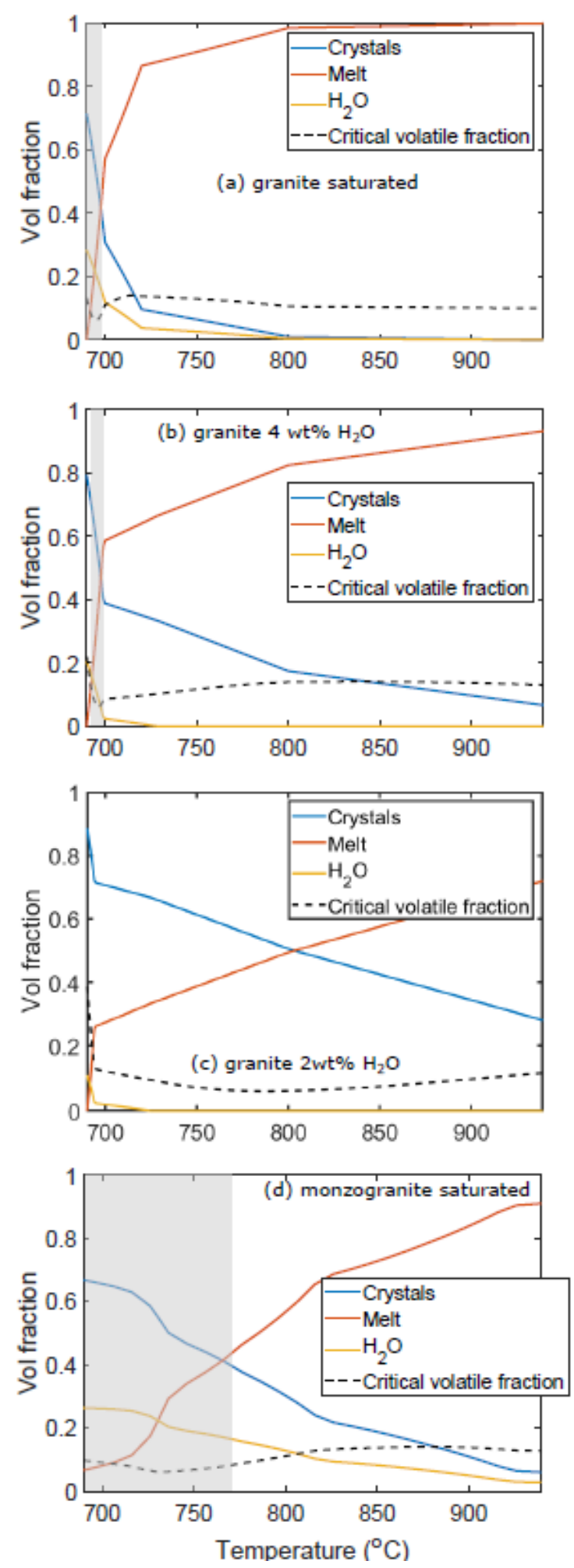

Figure 7: Proportions of crystals, melts, and exsolved volatiles before transport as a function of temperature. (a) a saturated Cape Ann granite, (b) Cape Ann granite with 4 wt\% H2O, (c) Cape Ann granite with $2 \mathrm{wt} \% \mathrm{H}_{2} \mathrm{O}$, (d) a saturated Mte Capanne monzogranite. The grey area shows the temperature range over which transport through channels happens, i.e. where the volatile curve is above the critical volatile fraction and the crystal fraction is between 0.4 and 0.7 . No transport occurs for the granite with $2 \mathrm{wt} \% \mathrm{H}_{2} \mathrm{O}$ (c), because the proportion of exsolved volatiles never exceeds the critical value. 

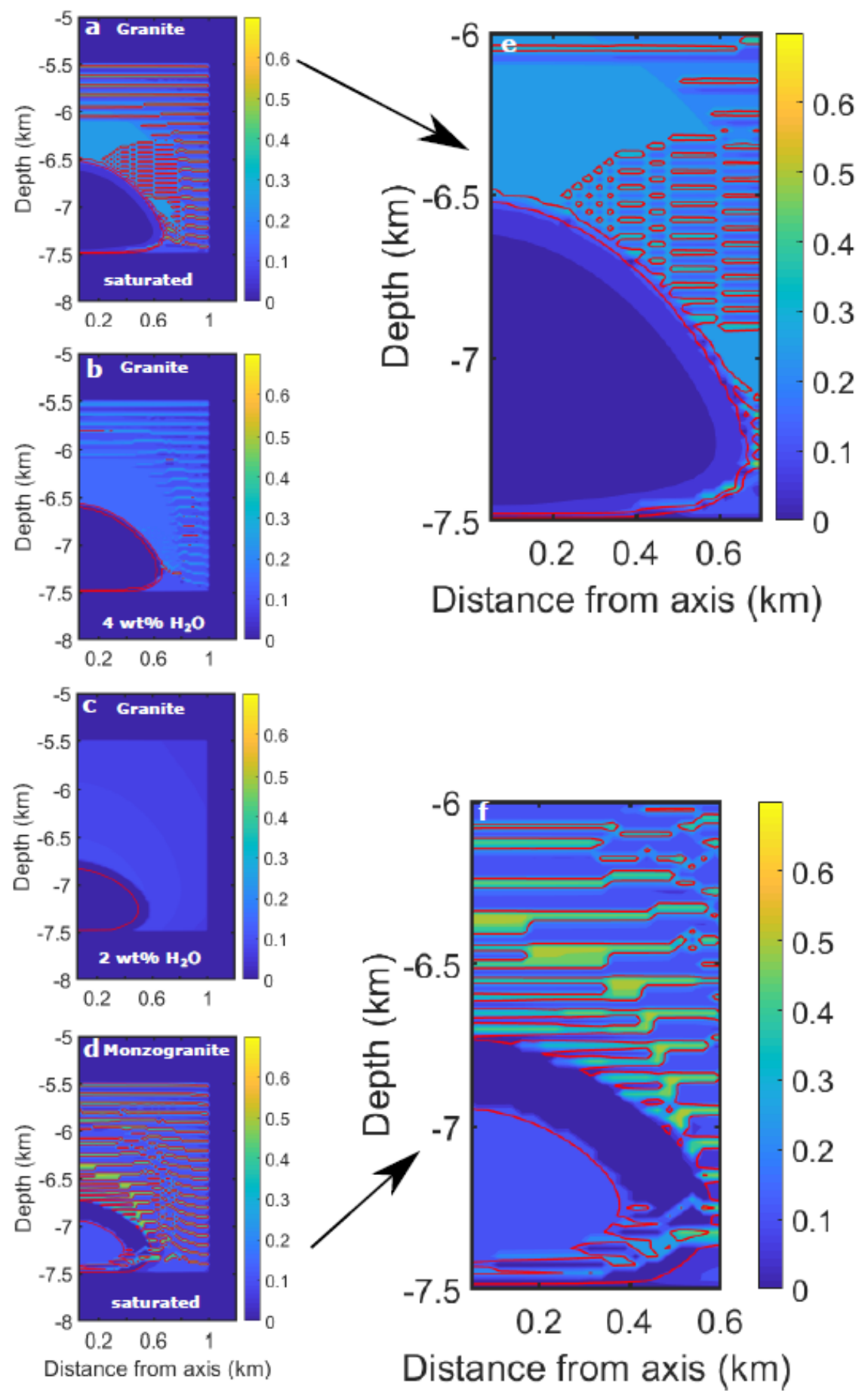

Figure 8: Snapshots of exsolved water volume fraction. In these simulations, 100-m sills were emplaced every 1,000 yrs during 20,000 yrs. All snapshots are at time 22,000 yrs, i.e 2000 yrs after the last sill emplacement. Results are shown for a Cape Ann granite composition that initially contains (a) 6 wt\% H2O, (b) 4 wt \% H2O, (c) 2 wt\% H2O, and (d) for the Mt. Capanne monzogranite that initially contains $6 \mathrm{wt} \% \mathrm{H}_{2} \mathrm{O}$. The red lines on the snapshots show the 0.4 and 0.7 crystal volume fraction isolines and delimit the areas where water in transported through channels. These areas are very thin in (a) and (b). In (c), there is no magma with crystal fraction below 40 vol\%. (e) and (f) are enlargement of (a) and (d), respectively. 


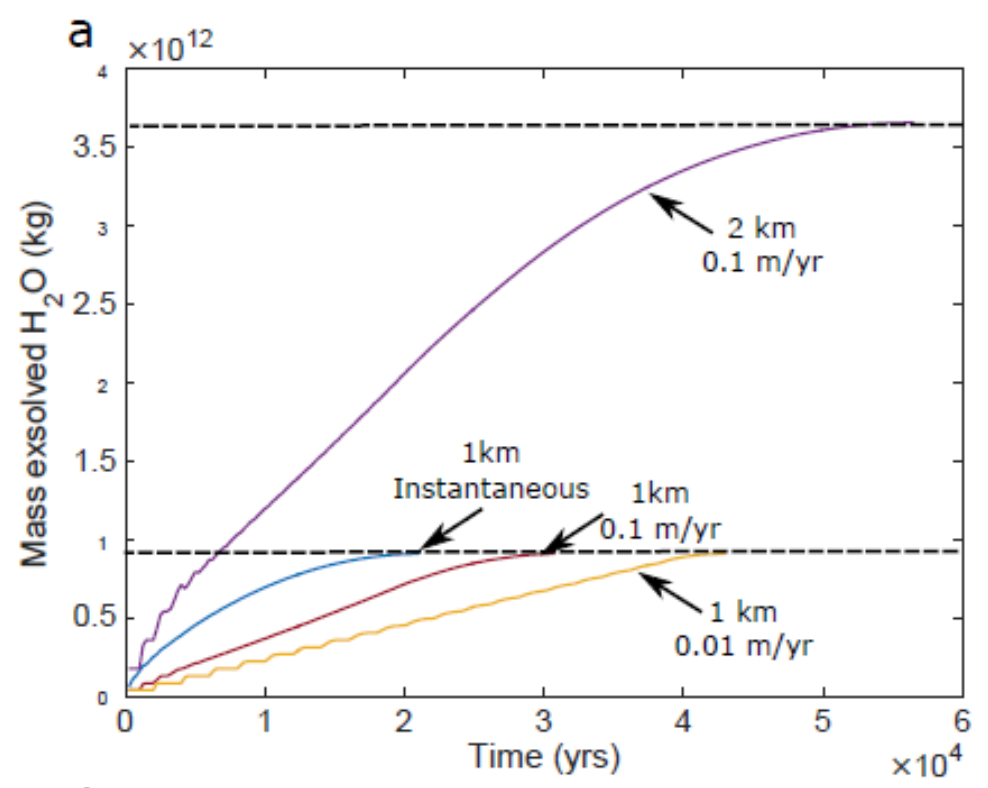

b

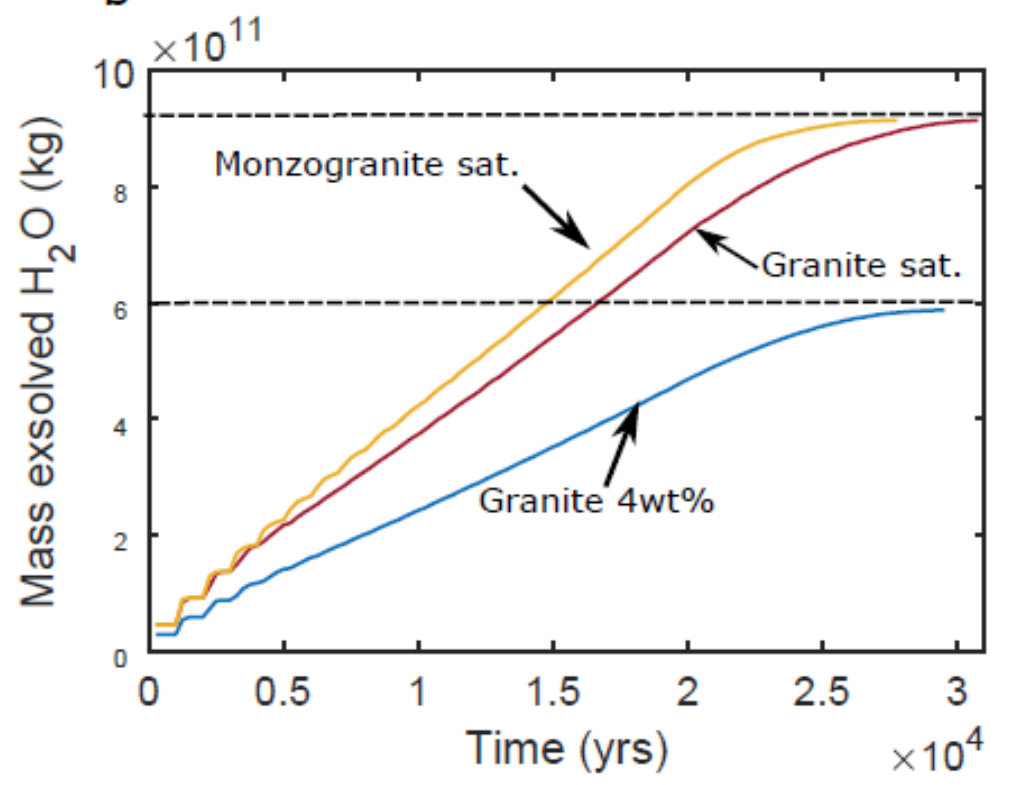

Figure 9: Cumulated mass of exsolved water available as a function of time. We assume that the volatiles in suspension as bubbles in the liquid magma are unavailable and are excluded from the calculation. (a) Exsolved water for different emplacement rates and sills radii corresponding to magma fluxes of $0.3 \mathrm{~km} 3 / \mathrm{yr}$ for $1 \mathrm{~km}$ radius and $0.1 \mathrm{~m} / \mathrm{yr}$ emplacement, $0.03 \mathrm{~km} 3 / \mathrm{yr}$ for $1 \mathrm{~km}$ radius and $0.01 \mathrm{~m} / \mathrm{yr}$ emplacement, and $1.26 \mathrm{~km}^{3} / \mathrm{yr}$ for $2 \mathrm{~km}$ radius and $0.1 \mathrm{~m} / \mathrm{yr}$ emplacement. The composition is Cape Ann water-saturated granite. (b) Exsolved water for different compositions of magma emplaced at the same rate of $0.01 \mathrm{~m} / \mathrm{yr}$ and same sill radius of $1 \mathrm{~km}$. The total and final mass of water exsolved is shown by the horizontal dashed lines. 


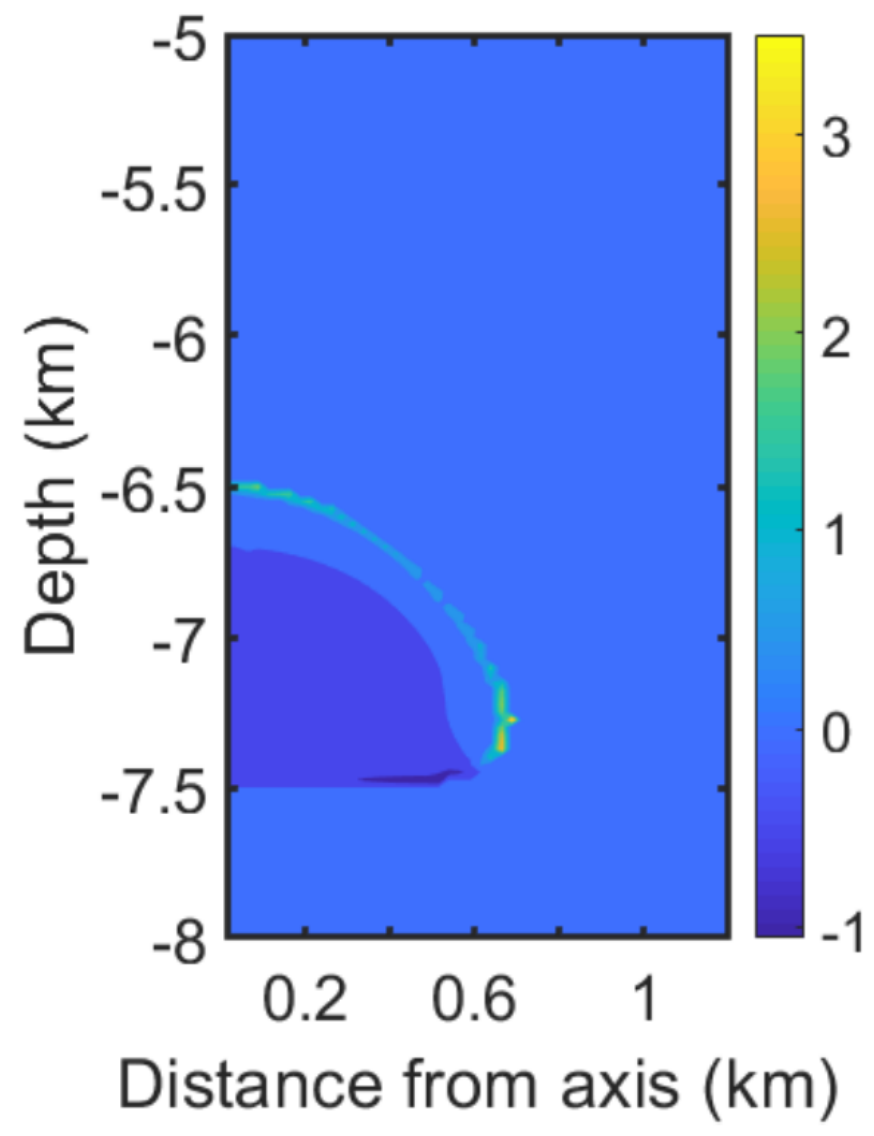

Figure 10: Effect of water loss on melt fractions. The colors show the difference in melt mass fractions in wt\% between a model that takes into account water loss and a model that neglects the effect of water loss on the melting curves. The composition is water-saturated Cape Ann granite. $100-\mathrm{m}$ sills were emplaced every 1000 yrs during $20,000 \mathrm{yrs}$. The snapshot is taken at time 22,000 yrs, which is 2000 yrs after the last sill emplacement. 